\title{
Climate effects on growth differ according to height and diameter along the stem in Pinus pinaster Ait.
}

\author{
Álvaro Rubio-Cuadrado ${ }^{(1)}$, \\ Andrés Bravo-Oviedo ${ }^{(2-3-4)}$, \\ Sven Mutke ${ }^{(2-3)}$, \\ Miren Del Río ${ }^{(2-3)}$
}

\section{Introduction}

Climate change projections for the Mediterranean region, based on global and regional climate model simulations, provide an overall picture of substantial drying and warming of the region, especially in the

\begin{abstract}
Climate-growth relationships in forest trees are increasingly the focus of research aimed at understanding and assessing responses to climate change. Many studies have been confined to annual radial growth at breast height as an easy-to-measure dendrological standard variable, although its validity as a proxy for overall annual growth patterns in trees has scarcely been addressed. In this study, we test this hypothesis by exploring additional information on climate-growth relationships as well as analyzing both the radial growth at different stem heights and the height increment. For this purpose, past annual radial growth and shoot elongation were measured in 10 dominant Pinus pinaster Ait. trees in a 130-year-old stand. Radial increments were measured on disks taken from five different trunk heights up to 15 meters. Height increments were obtained by measuring the distance between consecutive branch whorls, which appear as knots after sawing a longitudinal section of the stem. The relationships between climate and both radial growth and height increment were analyzed through Pearson's correlations and the response to extreme climatic episodes was analyzed using resilience indices. Results revealed that the climatic variables affecting growth were different for height and stem diameter. Additionally, in the case of stem diameter, the climatic variables affecting growth also depended on the height at which the sample was taken. Precipitation prior to bud break, both in the year in which the studied shoot elongation takes place and in the previous year, has a positive effect on height increment. Radial growth in the upper part of the stem was mainly influenced by spring temperatures and precipitation, whereas in the case of basal radial growth it was the autumn and winter temperatures and precipitation of the previous year to growth which had the greatest influence. Similarly, severe droughts cause greater decline in height increment, while the decline in radial growth of the upper part of stem is smaller than that of radial growth at breast height. In conclusion, the analysis of height increment and upper radial growth provides important information to complement the dendroclimatology data for radial growth at breast height, thus improving our understanding of the impact of climate change on tree growth.
\end{abstract}

Keywords: Dendrochronology, Climate Growth Response, Growth Allocation, Stem Analysis, Climate Sensitivity, Resilience

summer season. In a scenario with intermediate $\mathrm{CO}_{2}$ emissions, it is estimated that the decrease in precipitation will exceed $15 \%$ and that warming will reach $3.6{ }^{\circ} \mathrm{C}$ (Jacob et al. 2014). Since the middle of the $20^{\text {th }}$ century, the increasing impact of climate change on forest productivity due to changes in water availability and/or temperature is evident (Reyer et al. 2014). Therefore, studying climate-growth relationships can provide valuable information to assess the vulnerability of forests to cli-

(1) Departamento de Sistemas y Recursos Naturales, Escuela Técnica Superior de Ingeniería de Montes, Forestal y del Medio Natural, Universidad Politécnica de Madrid, Ciudad Universitaria s/n, E-28040 Madrid (Spain); (2) INIA, Forest Research Centre, Department of Silviculture and Forest Management, Crta. La Coruña km 7.5, E-28040 Madrid (Spain); (3) iuFOR, Sustainable Forest Management Research Institute, University of Valladolid \& INIA (Spain); (4) Department of Biogeography and Global Change, National Museum of Natural Sciences, Spanish National Research Council (MNCN, CSIC), Madrid (Spain)

@ Álvaro Rubio-Cuadrado (alvaro.rubio.cuadrado@upm.es)

Received: Dec 15, 2016 - Accepted: Jan 15, 2018

Citation: Rubio-Cuadrado Á, Bravo-Oviedo A, Mutke S, Del Río M (2018). Climate effects on growth differ according to height and diameter along the stem in Pinus pinaster Ait. iForest 11: 237-242. - doi: 10.3832/ifor2318-011 [online 2018-03-12] 
mate change and possible changes in productivity. Furthermore, such studies allow adaptive management measures to be developed in order to mitigate the effects of climate change (Sohn et al. 2012).

Resampling diameters at breast height is considered an easy-to-measure proxy for stem growth. However, several studies have shown that radial growth at breast height may not be representative of radial growth patterns along the stem (Brookhouse \& Brack 2008, Chhin et al. 2010, Kerhoulas \& Kane 2012, Sohn et al. 2012, Latte et al. 2016). Differing rates of growth along the stem can be caused by vertical gradients in hydraulic constraints and priorities for carbon allocation. Due to gravitational effects on xylem tensions, the sensitivity of radial growth to climate increases consistently with height along the stem (Kerhoulas \& Kane 2012).

Although diameter growth is influenced by age, stand density, and natural or anthropogenic disturbances, methods to remove these effects have been developed for the purpose of comparing different stands (Speer 2010). However, the site factors that determine productivity are more correlated with stand height than stand diameter, since the latter depends largely on the stand density and therefore on forest management. Dominant height growth in even-aged stands is scarcely modified by silviculture and is frequently used as a site productivity indicator (Skovsgaard \& Vanclay 2008). Therefore, given the dependence of dominant tree height growth on climatic conditions, this relationship may be of great interest when analyzing the possible impact of climate change on forest productivity (Vizcaíno-Palomar et al. 2017) at specific sites.

Height increment in monocyclic pines is mainly predetermined by the climatic conditions during the year previous to the growth (Salminen et al. 2009), whereas the climate during the growth period itself (Hover et al. 2017) also influences polycyclic pines. As with radial growth series, height increment series can be synchronized and standardized, and the response to climatic variables can be explored following the standard methods of dendrochronology (Salminen et al. 2009). However, it is more difficult to measure height increment series than it is to measure tree rings in a radial core for radial growth. Moreover, it frequently requires destructive sampling (Salminen et al. 2009).

Extreme episodes such as drought, heavy rains and extreme heat or cold events can lead not only to abrupt declines in growth but can also affect the growth and production of the forest for one year or even several successive years. Resilience of an individual, broadly defined, is its capacity to recover after disturbance (Lloret et al. 2011). Most resilience studies focus on tree dieback and forest vulnerability, and generally use growth samples taken at breast height (Pretzsch et al. 2013, Sánchez-Salguero et al. 2013). Although a few studies addressing resilience have used height increment series (Rais et al. 2014), to our knowledge none have used tree-ring width series from different stem heights.

The main objective of this study was to determine whether height increment and radial growth series sampled at different stem heights can contribute to improve our understanding of the effects of climatic conditions on the growth of Mediterranean Maritime pine (Pinus pinaster Ait.). The specific questions addressed in our study are: (i) how does sensitivity to climate variability differ between height increment and tree-ring width along the length of the stem? (ii) How do height increment and diameter increments along the stem respond to extreme climatic events? (iii) Which climate variables influence tree height increment and tree-ring width at the study site? Our main hypothesis was that height and diameter growth along the stem respond differently to climatic conditions and therefore provide valuable information for evaluating the effects of climate change on productivity, as well as tree vulnerability to extreme climatic events.

\section{Material and methods}

\section{Study site and field data}

Data was collected from a regeneration felling in a permanent plot belonging to INIA-CIFOR (plot ID: Soria-44) in winter 2009. The plot is situated in an artificially regenerated, even-aged, 130-year-old stand of Pinus pinaster Ait., which is a polycyclic species. The plot, located near Bayubas de Arriba, Soria, Spain $\left(41^{\circ} 33^{\prime} \mathrm{N} 02^{\circ} 55^{\prime} \mathrm{W}\right)$ at an elevation of $1000 \mathrm{~m}$ a.s.l., is gently sloping (5\%) and has sandy soils.

The climatic data used in this work is taken from the El Burgo de Osma weather station, which is located at approximately $12 \mathrm{~km}$ from the stand $\left(A E M E T^{\circ}, 41^{\circ} 35^{\prime} \mathrm{N}\right.$, $03^{\circ} 04^{\prime} \mathrm{W}, 895 \mathrm{~m}$ a.s.l.) and provides records for the period from 1932 to 2008. Missing data were estimated by linear regression, which relates climatic variables from this station and from the Bayubas de Abajo weather station (AEMET ${ }^{\odot}, 41^{\circ} 32^{\prime} \mathrm{N}$, $02^{\circ} 55^{\prime} \mathrm{W}, 1000 \mathrm{~m}$ a.s.l.), the latter providing records for the period 1955-2002 (see Fig. S1 in Supplementary material for linear regressions relating both weather stations).

The site has a Mediterranean climate. In the period 1932-2008, mean annual precipitation was $520 \mathrm{~mm}$, mean annual temperature was $10.4{ }^{\circ} \mathrm{C}$, highest temperature was $40.0{ }^{\circ} \mathrm{C}$, lowest temperature was $-22.0{ }^{\circ} \mathrm{C}$, mean maximum temperature of the hottest month was $28.6^{\circ} \mathrm{C}$, and mean minimum temperature of the coldest month was $-2.0{ }^{\circ} \mathrm{C}$. The average drought length was two months (July-August).

Ten dominant trees, free of visible damage and which had never been pruned along the stem, were felled in the experi- mental plot to enable sampling. The mean DBH of these trees ( \pm standard deviation, SD) was $48.4 \pm 1.8 \mathrm{~cm}$, mean height $17.7 \pm$ $0.9 \mathrm{~m}$ and mean height of the first green branch $12.2 \pm 0.8 \mathrm{~m}$. Previous studies have proven that a sample of ten trees from a given stand is sufficient to describe the development of height increment and radial growth along the stem (Brookhouse \& Brack 2008, Salminen et al. 2009, Latte et al. 2016).

Once a tree had been felled, its stem was sawn longitudinally to measure the annual height increments according to the location of the branch whorls along the tree trunk. Height increments were measured to the nearest centimeter and dated in the field. In addition, we sampled five disks per tree from different stem heights: basal ( 0.3 $\mathrm{m})$, breast height $(1.3 \mathrm{~m})$ and at heights of about 8,12 and $15 \mathrm{~m}$. The last three heights varied depending on total tree height and branch distribution. The disks were taken to the laboratory and sanded with progressively finer grades of sandpaper (ANSI 80, $120,220,320$ and 400 grit). Two or more radii were selected on each disk according to the eccentricity of each one, avoiding the vicinity of reaction wood. The rings were measured to the nearest $0.01 \mathrm{~mm}$ using the Lintab ${ }^{\circledast}$ device and the TSAP-Win ${ }^{\circledR}$ software (Rinntech, Heidelberg, Germany).

\section{Chronology statistics}

Annual tree radii increments were crossdated, listing the characteristics rings. All the tree radii were then compared to identify shared characteristics rings. Annual height increment series were also crossdated, listing any increments that were especially large or small and the years with multiple shoot growths. The visual crossdating of tree-ring series was further verified using the COFECHA program (Holmes 1997) with a rigidity of spline of 32 years. This rigidity is considered the optimum for error detection (Grissino-Mayer 2001). As regards the height chronologies, only the growths from 1930 to 2008 were used because cross-dating revealed that measurements of growth prior to this period may not be sufficiently reliable, due to the fact that young trees often present multiple shoots as well as greater variability in height growth among individuals, thus complicating annual growth reconstruction (Fritts 2001).

The ARSTAN software (Holmes 1997) was employed to create residual chronologies of tree-ring width for each sampling height (basal, 1.3, 8, 12 and $15 \mathrm{~m}$ ) as well as for height increment using a double detrending procedure: a negative exponential curve to remove age trend and a cubic smoothing spline using a rigidity of 32 years. This removes the low-to-medium frequency disturbance components from the data. In order to remove persistence that may remain after the spline, an autoregressive (AR1) model was fitted to the measurement series. 
The qualities of the chronologies were assessed using the following statistical parameters: mean correlation coefficient among tree-growth series and master reference chronology for each group of chronologies (basal, 1.3, 8, 12 and $15 \mathrm{~m}$ treering width series and height increment series); standard deviation; autocorrelation (Grissino-Mayer 2001); mean sensitivity (MS), which expresses the degree by which one or more causal factors are reflected by a tree-ring series (Schweingruber 1996, Grissino-Mayer 2001); signal-tonoise ratio, the proportion of the variability explained by climate or other causal factors divided by the residual or unexplained variability (Fritts \& Swetnam 1989, Holmes 1997). These parameters were computed both for their entire length and for the period common to all chronologies using $\mathrm{CO}$ FECHA, except the signal-to-noise ratio, which was computed using ARSTAN.

The dependence between radial growth and height growth was studied by crosscorrelation analysis. These analyses were based on the residual chronologies and were calculated both with and without a time lag of one year.

\section{Response to extreme climatic events}

To study the growth response to extreme climatic episodes we analyzed the most important reductions in growth. Negative pointer years were determined as those years in which at least $75 \%$ of the growth series for each group of chronologies showed a growth decrease of at least $40 \%$ relative to the average growth in the 4 preceding years (Schweingruber et al. 1990). This allowed the characterization of the following negative pointer years: 1896, 1945 and 2005 in the basal tree-ring series; 1896 and 2005 in the $1.3 \mathrm{~m}$ tree-ring series; 1918, 1945 and 2005 in the $8 \mathrm{~m}$ series; 1945 and 2005 in the $12 \mathrm{~m}$ series; only 2005 in the $15 \mathrm{~m}$ series and 2006 in the height increment series.

The growth response to the pointer years 1896, 1918, 1945 and 2005 and the ability to recover pre-disturbance growth levels af- ter disturbance were estimated for the different groups of increment series through the resistance $(R t)$ and resilience $(R s)$ indices (Lloret et al. 2011 - eqn. 1, eqn. 2):

$$
\begin{aligned}
& R t=\frac{G_{i}}{G_{i-4}} \\
& R s=\frac{G_{i+4}}{G_{i-4}}
\end{aligned}
$$

where $G_{i}$ is the growth of year $i$ and $i-4$ and $i+4$ are 4-year-long pre- and post-disturbance periods based on previous studies (Gazol et al. 2017). For the pointer year 2005 we only used a 3-year-long post-disturbance period as we only had growth data up to 2008. As shoot length is heavily influenced by bud formation in the previous year of growth, instead of calculating the Rt of the pointer year 2006 in the height increment series, we calculated the Rt of 1945 and 2005 with a time lag of one year $(t+1)$, shifting the numerator for growth of one year after the disturbance but maintaining a constant denominator. In addition, the Rs index of the height increment series was calculated without the first post-disturbance year, that is, with a period of only 3 years (1947-1949) after the pointer year of 1945 and 2 years (20072008) after the pointer year of 2005. The pointRes package (Van Der Maaten-Theunissen et al. 2015) was used to calculate pointer years and resilience indices. We compared index values among groups of chronologies using the t-test for independent samples with different variances.

\section{Climate-growth relationships}

Relationships between growth and climate were analyzed through the software DendroClim 2002 (Biondi \& Waikul 2004) using Pearson's correlation coefficients between the residual chronologies and the monthly precipitation / monthly mean temperature. As regards radial growth, correlation coefficients were calculated from September of the previous year to November of the year of growth analyzed, as the climate in autumn can influence the growth of the following year. Furthermore, in fa- vorable years there may be a second vegetative stage between the end of summer and the middle of autumn (Del Río et al. 2014). With respect to the height increment series, this interval was extended to the entire previous year for shoot elongation, because the corresponding terminal buds in conifers are pre-formed the year before and strongly influence final shoot length (Salminen et al. 2009, Hover et al. 2017).

\section{Results and discussion}

\section{Height and diameter increment} chronologies

Average correlations of the growth series with their master reference series ranged between 0.79 and 0.89 for tree-ring width series, and 0.61 in the case of height increment series with $p<0.001$ (Tab. 1), reflecting good to excellent inner coherence of the data set (Grissino-Mayer 2001, Bogino \& Bravo 2008, Salminen et al. 2009). The relatively high MS values suggest that the tree-ring widths accurately reflect causal factors (climate) and signal-to-noise ratio values suggest that the proportion of explainable variation due to causal factors is sufficient (Bogino \& Bravo 2008, Speer 2010). Therefore, all growth series were appropriate for studying their relationship with climate.

The raw chronologies of tree-ring width and height increment showed a time lag of one year between maximum and minimum values (Fig. 1). Equally, the higher correlations between radial and height increment series were produced with the same time lag (Tab. 2).

Height increment series presented higher values for sensitivity and standard deviations and scarce autocorrelation, which is concordant with previous studies (Salminen et al. 2009). However, they also showed lower correlations with their master reference series, suggesting that their high variability may be due to genetic or microsite differences rather than to a better response to climatic variations.

Tab. 1 - Statistical parameters of the chronology series. Signal-to-noise ratio of the 15 meter tree-ring chronology is missing because

\begin{tabular}{|c|c|c|c|c|c|c|}
\hline \multirow{2}{*}{ Chronology } & \multicolumn{2}{|c|}{ Tree-ring width series } & \multirow[b]{2}{*}{8} & \multirow[b]{2}{*}{12} & \multirow[b]{2}{*}{15} & \multirow{2}{*}{$\begin{array}{r}\text { Height } \\
\text { increment } \\
\text { series }\end{array}$} \\
\hline & Basal & 1.3 & & & & \\
\hline First year & 1871-81 & $1878-90$ & $1909-20$ & 1932-55 & 1961-91 & 1930 \\
\hline Correlation with master & 0.79 & 0.79 & 0.84 & 0.88 & 0.89 & 0.61 \\
\hline Standard deviation & 0.42 & 0.43 & 0.42 & 0.46 & 0.53 & 0.57 \\
\hline Autocorrelation & 0.85 & 0.85 & 0.83 & 0.58 & 0.23 & 0.27 \\
\hline Mean sensitivity & 0.27 & 0.27 & 0.25 & 0.26 & 0.31 & 0.36 \\
\hline Signal-to-noise ratio & 11.34 & 14.4 & 16.79 & 32.14 & - & 9.76 \\
\hline First year & 1961 & 1961 & 1961 & 1961 & $1961-91$ & 1961 \\
\hline Correlation with master & 0.84 & 0.84 & 0.85 & 0.9 & 0.89 & 0.57 \\
\hline Standard deviation & 0.49 & 0.5 & 0.47 & 0.49 & 0.53 & 0.59 \\
\hline Autocorrelation & 0.53 & 0.48 & 0.58 & 0.52 & 0.23 & 0.19 \\
\hline Mean sensitivity & 0.28 & 0.29 & 0.28 & 0.27 & 0.31 & 0.38 \\
\hline
\end{tabular}
of the short time span. 


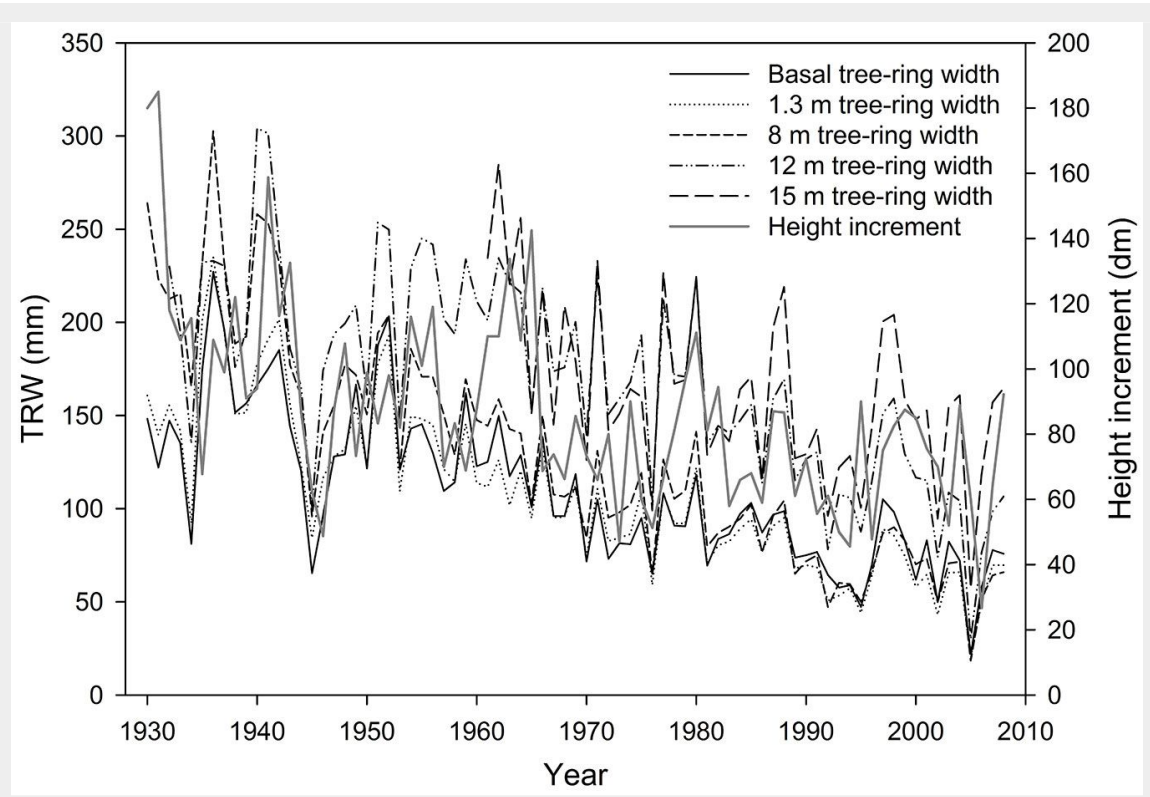

Fig. 1 - Chronologies of height increment and tree-ring width (TRW).

Tab. 2 - Correlation coefficients between residual chronologies of basal and $15 \mathrm{~m}$ treering width and height increment series. The level of significance ( $p$-value) is in parentheses. $t+1$ has been calculated with a time lag of one year. $(*): p<0.05 ;(* *): p<0.01$; $(* * *): p<0.001$.

\begin{tabular}{lllll}
\hline- & Basal & $\mathbf{1 5 ~} \mathrm{m}$ & Height & Height $t+1$ \\
\hline Basal & 1 & - & - & - \\
\multirow{2}{*}{$15 \mathrm{~m}$} & $0.850^{* * *}$ & 1 & - & - \\
& $(0.000)$ & & & - \\
\multirow{2}{*}{ Height } & 0.051 & 0.252 & 1 & 1 \\
\multirow{2}{*}{ Height $t+1$} & $(0.740)$ & $(0.095)$ & & 1 \\
& $0.480^{* *}$ & $0.514^{* * *}$ & 0.095 & $(0.537)$ \\
\hline
\end{tabular}

The $15 \mathrm{~m}$ tree-ring series showed the Kerhoulas \& Kane 2012, Latte et al. 2016). highest values of MS and correlation with the master reference series and the lowest autocorrelation value (Tab. 1). Likewise, the signal-noise ratio increased with sample height of the tree-ring series. Therefore, the response of radial growth to climatic variations increased with height along the stem, as previously reported by other studies (Brookhouse \& Brack 2008, The growth response to the pointer years was similar in all tree-ring series (Fig. 2) except in the $15 \mathrm{~m}$ series, which had significantly higher $R t$ values for the pointer year $2005(p=0.002)$. Bouriaud et al. (2005) also highlighted the lesser effect of drought on the upper part of the stem. Similarly, height increment series showed significantly higher $R t$ values for the pointer year $2005(p<0.001)$. The $R t$ values of the height increment series for the pointer years $1945(t+1)$ and $2005(t+1)$, both with a time lag of one year, also presented significant differences with regard to the treering series with a time lag of one year $(p<$ 0.001 in both), but showed no differences with regard to $R t$ values of the tree-ring series for 1945 and 2005 without one year time lag. In contrast to other species (Rais et al. 2014) the declines in height increment series were found to be no greater than those of tree-ring series. Therefore, our results do not support the hypothesis that the tree may change its allocation pattern from crown expansion and carbon assimilation to root extension in order to capture additional water (Pretzsch 2010).

No significant differences were found in Rs between series. Like previous studies, $R s$ values gradually rise over time, with better growth recoveries as age increases ( $\mathrm{Ga}$ zol et al. 2017). In general, complete tree growth recovery is not reached within the four post-disturbance years. This is usually the case with conifers growing in mesic sites (Orwig \& Abrams 1997) as opposed to conifers adapted to xeric sites, which recover pre-drought growth more rapidly (Martín-Benito et al. 2008, Gazol et al. 2017). According to our results, extrapolating a given decline in increment at breast height to the whole stem can result in errors; on the one hand underestimating the total height increment decline (which occurs over two consecutive years following drought) and on the other, overestimating the decline in growth of the tree-ring series at $15 \mathrm{~m}$.

\section{Climatic drivers of height and diameter increments}

Correlation with climatic variables differed for height increment and tree-ring

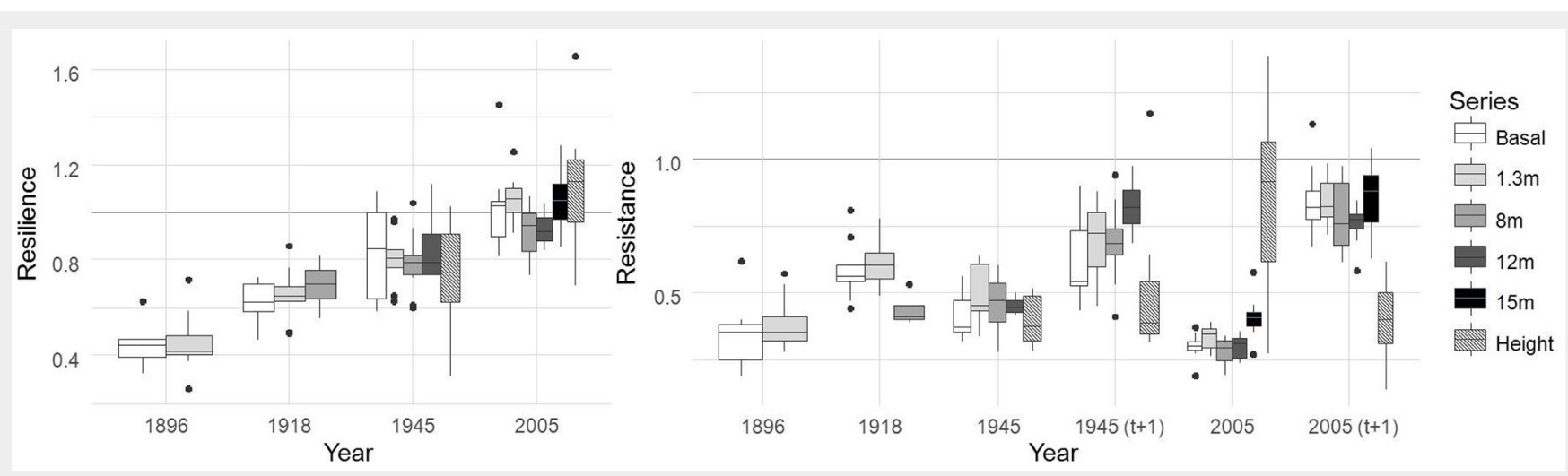

Fig. 2 - Resistance and resilience recovery indices for all groups of chronologies considering the selected negative pointer years $(1896,1918,1945$ and 2005). Resistance is also shown with a time lag of one year $(t+1)$ for the 1945 and 2005 pointer years. 
Tab. 3 - Pearson's correlation coefficients of the residual chronologies with monthly precipitations (P) and monthly mean tempera tures $(T)$. Asterisks mark the statistically significant $(p<0.05)$ correlation coefficients with a $95 \%$ confidence interval. Residual chronologies: Height is the height increment chronology; Basal, $1.30 \mathrm{~m}, 8 \mathrm{~m}, 12 \mathrm{~m}, 15 \mathrm{~m}$ are the tree-ring width chronologies.

\begin{tabular}{|c|c|c|c|c|c|c|c|c|c|c|c|c|c|}
\hline \multirow{2}{*}{ Year } & \multirow{2}{*}{ Month } & \multicolumn{6}{|c|}{ Residual Chronology vs. P } & \multicolumn{6}{|c|}{ Residual Chronology vs. T } \\
\hline & & Height & $15 \mathrm{~m}$ & $12 \mathrm{~m}$ & $8 \mathrm{~m}$ & $1.30 \mathrm{~m}$ & Basal & Height & $15 \mathrm{~m}$ & $12 \mathrm{~m}$ & $8 \mathrm{~m}$ & $1.30 \mathrm{~m}$ & Basal \\
\hline \multirow{12}{*}{$\begin{array}{l}\text { Previous } \\
\text { year }\end{array}$} & Jan & 0.11 & - & - & - & - & - & 0.02 & - & - & - & - & - \\
\hline & Feb & $0.35^{*}$ & - & - & - & - & - & 0.18 & - & - & - & - & - \\
\hline & Mar & 0.15 & - & - & - & - & - & 0.13 & - & - & - & - & - \\
\hline & Apr & 0.13 & - & - & - & - & - & 0 & - & - & - & - & - \\
\hline & May & 0.07 & - & - & - & - & - & -0.03 & - & - & - & - & - \\
\hline & Jun & -0.01 & - & - & - & - & - & -0.03 & - & - & - & - & - \\
\hline & Jul & 0.17 & - & - & - & - & - & 0.03 & - & - & - & - & - \\
\hline & Aug & -0.02 & - & - & - & - & - & $0.17^{*}$ & - & - & - & - & - \\
\hline & Sep & $0.24^{*}$ & 0.07 & 0 & 0.05 & -0.08 & -0.08 & $0.21^{*}$ & 0 & 0.02 & 0.06 & -0.01 & -0.03 \\
\hline & Oct & 0.03 & 0.03 & -0.05 & 0 & -0.05 & -0.08 & 0.01 & -0.01 & -0.07 & -0.13 & -0.1 & -0.09 \\
\hline & Nov & -0.11 & $0.31^{*}$ & $0.24^{*}$ & $0.25^{*}$ & $0.28^{*}$ & $0.34^{*}$ & -0.1 & 0.24 & 0.19 & 0.16 & $0.27^{*}$ & $0.30^{*}$ \\
\hline & Dec & -0.1 & $0.25^{*}$ & $0.19^{*}$ & $0.21^{*}$ & $0.23^{*}$ & $0.27^{*}$ & -0.09 & 0.2 & $0.28^{*}$ & $0.30^{*}$ & $0.37^{*}$ & $0.39^{*}$ \\
\hline \multirow{11}{*}{$\begin{array}{l}\text { Growth } \\
\text { year }\end{array}$} & Jan & 0.19 & $0.39^{*}$ & $0.37^{*}$ & $0.41^{*}$ & $0.37^{*}$ & $0.37^{*}$ & 0.11 & $0.31^{*}$ & $0.29^{*}$ & $0.30^{*}$ & $0.32^{*}$ & $0.35^{*}$ \\
\hline & Feb & 0.07 & 0.1 & 0.18 & $0.21^{*}$ & $0.21^{*}$ & $0.23^{*}$ & -0.02 & $0.43^{*}$ & $0.35^{*}$ & $0.32^{*}$ & $0.33^{*}$ & $0.35^{*}$ \\
\hline & Mar & $0.22^{*}$ & 0.15 & $0.25^{*}$ & $0.26^{*}$ & $0.25^{*}$ & $0.27^{*}$ & 0.05 & -0.01 & 0.12 & 0.08 & 0.05 & 0.07 \\
\hline & Apr & 0.16 & $0.34^{*}$ & $0.25^{*}$ & $0.25^{*}$ & 0.16 & 0.12 & -0.07 & $0.32^{*}$ & 0.05 & 0.06 & 0.16 & 0.17 \\
\hline & May & 0.05 & $0.35^{*}$ & $0.34^{*}$ & $0.31^{*}$ & $0.34^{*}$ & $0.30^{*}$ & 0.03 & $-0.28^{*}$ & $-0.38^{*}$ & $-0.38^{*}$ & $-0.38^{*}$ & $-0.32^{*}$ \\
\hline & Jun & -0.02 & $0.29^{*}$ & 0.14 & 0.17 & 0.17 & 0.17 & -0.01 & -0.22 & -0.14 & -0.21 & -0.17 & -0.15 \\
\hline & Jul & 0.03 & 0.25 & $0.28^{*}$ & $0.25^{*}$ & $0.27^{*}$ & $0.30^{*}$ & $-0.25^{*}$ & $-0.35^{*}$ & -0.12 & $-0.21^{*}$ & -0.1 & -0.05 \\
\hline & Aug & -0.1 & -0.17 & -0.1 & -0.13 & -0.09 & -0.05 & -0.07 & 0.11 & 0.09 & 0.02 & 0.04 & 0.08 \\
\hline & Sep & 0.08 & -0.09 & 0.13 & 0.08 & 0.13 & 0.21 & -0.13 & $0.42^{*}$ & $0.26^{*}$ & $0.23^{*}$ & $0.27^{*}$ & $0.26^{*}$ \\
\hline & Oct & -0.12 & -0.1 & -0.12 & -0.06 & -0.09 & -0.04 & -0.03 & 0.04 & -0.06 & -0.09 & 0 & -0.02 \\
\hline & Nov & 0.05 & -0.17 & -0.1 & -0.09 & -0.15 & -0.12 & -0.13 & $-0.27^{*}$ & $-0.28^{*}$ & $-0.24^{*}$ & -0.21 & -0.17 \\
\hline
\end{tabular}

width. In the case of the latter, this correlation also differed depending on the height at which the sample was taken (Tab. 3). We found significant $(p<0.05)$ positive responses of height increment to rainfall just before the start of the growing season, both in the previous year (bud formation) and in the year in which the studied shoot elongation takes place. Rainfall in September of the previous year was also significantly correlated, possibly because it influences bud formation which finishes during autumn (Hover et al. 2017). Tree-ring width seems to be mainly related to the amount of precipitation from November to July, which replenishes the soil water reserves up to the summer, as reported in similar studies conducted under Mediterranean climatic conditions (Bogino \& Bravo 2008, Del Río et al. 2014). The correlation with tree-ring width was positive for each month from November to July, although there were some differences in the significance between chronologies in the months from February onwards, depending on the sample height. The correlations with precipitation in the case of the upper stem begin to be significant $(p<0.05)$ in spring, whereas for basal radial growth, this occurs in winter. During the period of crown activity, which coincides with spring and summer in the Mediterranean climate (Hover et al. 2017), it is possible that most of the nutrients are used by the crown and the part of the stem which is closest to the crown, while the lower stem benefits from stored carbon (Fritts 2001). The low correlation between ring width at the stem base and precipitation during the active crown period, as well as the high correlation with the precipitation over the previous months may be due to a dependency of the cambium on carbon reserves collected during these months (Fritts 2001).

Height increment was directly correlated with late summer temperature in the previous year of growth and low July temperature of the current year. Tree-ring width was positively correlated with winter and late summer temperatures and negatively correlated with May and July temperatures (Tab. 3). These results highlight the importance of late summer temperature for the growth of $P$. pinaster at the study site, which may present a bimodal pattern of growth with reactivation in late summer (Hover et al. 2017). Temperature seems to be more important for growth than reported in other studies on the same species at nearby sites (Bogino \& Bravo 2008), possibly because climate trends at local level can differ from regional trends, due to the influence of the topography, slope, winds or other local factors that add local variability to climatic trends. The relationships with temperature were similar for all ring-width samples with the exception of the 15 meter series, which showed higher correlations in the active crown period during spring and summer (Hover et al. 2017), and also with the exception of the previous autumn, as there was a higher correlation with stem base growth, which may be due to its dependency on the carbon reserves collected over these months.

\section{Conclusions}

Our results reveal that height increment and radial growth responses to climatic variability in the middle and especially up- per stem differ from the radial growth response at breast height, the latter being less sensitive to climate. If we only consider growth at breast height, the influence of late summer climatic conditions or disturbances such as droughts on tree growth may be underestimated, leading to lower accuracy when estimating the impact of climate change on tree productivity, carbon dioxide capture and adaptation of tree species. Furthermore, these results could contribute to the development of appropriate forest management practices aimed at adapting to and mitigating the effects of climate change.

The results of this study are of local value for Pinus pinaster. Similar studies with other species and/or sites need to be conducted to obtain more generally applicable results.

\section{Acknowledgments}

The study was partially supported by the projects AGL2011-29701-C02.01 and AT10007. We also acknowledge the Spanish State Meteorological Agency (AEMET), Ministry of Agriculture, Food and Environment, for granting access to the meteorological data.

\section{References}

Biondi F, Waikul K (2004). DENDROCLIM2002: a $\mathrm{C}_{+}+$program for statistical calibration of climate signals in tree-ring chronologies. Computers and Geosciences 30: 303-311. - doi: 10.1016/j. cageo.2003.11.004

Bogino SM, Bravo F (2008). Growth response of Pinus pinaster Ait. to climatic variables in central Spanish forests. Annals of Forest Science 65: 506-506. - doi: 10.1051/forest:2008025 
Bouriaud O, Leban J-M, Bert D, Deleuze C (2005). Intra-annual variations in climate influence growth and wood density of Norway spruce. Tree Physiology 25: 651-660. - doi: 10.1093/tree phys/25.6.651

Brookhouse M, Brack C (2008). The effect of age and sample position on eucalypt tree-ring width series. Canadian Journal of Forest Research 38: 1144-1158. - doi: 10.1139/X07-184

Chhin S, Hogg EH, Lieffers VJ, Huang S (2010). Growth-climate relationships vary with height along the stem in lodgepole pine. Tree Physiology 30: 335-345. - doi: 10.1093/treephys/tpp120 Del Río M, Rodríguez-Alonso J, Bravo-Oviedo A, Ruíz-Peinado R, Cañellas I, Gutiérrez E (2014). Aleppo pine vulnerability to climate stress is independent of site productivity of forest stands in southeastern Spain. Trees 28: 12091224. - doi: 10.1007/s00468-014-1031-0

Fritts HC, Swetnam TW (1989). Dendroecology: a tool for evaluating variations in past and present forest environments. Advances in Ecological Research 19: 111-188. - doi: 10.1016/S0065-25 04(08)60158-0

Fritts HC (2001). Tree rings and climate. The Blackburn Press, New Jersey, USA, pp. 584. [online] URL: http://books.google.com/books? id=mkjsuFdwjeoC

Gazol A, Ribas M, Gutiérrez E, Camarero JJ (2017). Aleppo pine forests from across Spain show drought-induced growth decline and partial recovery. Agricultural and Forest Meteorology 232: 186-194. - doi: 10.1016/j.agrformet.2016. 08.014

Grissino-Mayer HD (2001). Evaluating crossdating accuracy: a manual and tutorial for the computer program COFECHA. Tree-Ring Research 57: 205-221. [online] URL: http://hdl.handle.net/ 10150/251654

Holmes RL (1997). The dendrochronology program library. Version 2.1 user's manual. The International Tree Ring Data Bank Program. Laboratory of Tree-Ring Research, University of Arizona, Tucson, USA, pp. 108.

Hover A, Buissart F, Caraglio Y, Heinz C, Pailler F, Ramel $M$, Vennetier M, Prévosto B, Sabatier $S$ (2017). Growth phenology in Pinus halepensis Mill.: apical shoot bud content and shoot elongation. Annals of Forest Science 74: 39. - doi: 10.1007/s13595-017-0637-y

Jacob D, Petersen J, Eggert B, Alias A, Christensen OB, Bouwer LM, Braun A, Colette A, Deque M, Georgievski G, Georgopoulou E, Gobiet A, Menut L, Nikulin G, Haensler A, Hempelmann $\mathrm{N}$, Jones C, Keuler K, Kovats S, Kroener N, Kotlarski S, Kriegsmann A, Martin E, Meijgaard E, Moseley C, Pfeifer S, Preuschmann S, Raderma- cher C, Radtke K, Rechid D, Rounsevell M, Samuelsson $\mathrm{P}$, Somot $\mathrm{S}$, Soussana JF, Teichmann C, Valentini $R$, Vautard $R$, Weber $B$, Yiou $P$ (2014). EURO-CORDEX: new high-resolution climate change projections for European impact research. Regional Environmental Change 14: 563-578. - doi: 10.1007/s10113-013-0499-2

Kerhoulas LP, Kane JM (2012). Sensitivity of ring growth and carbon allocation to climatic variation vary within ponderosa pine trees. Tree Physiology 32: 14-23. - doi: 10.1093/treephys/tpr 112

Latte N, Lebourgeois F, Claessens H (2016). Growth partitioning within beech trees (Fagus sylvatica L.) varies in response to summer heat waves and related droughts. Trees - Structure and Function 30: 189-201. - doi: 10.1007/s00468015-1288-y

Lloret F, Keeling EG, Sala A (2011). Components of tree resilience: effects of successive lowgrowth episodes in old ponderosa pine forests. Oikos 120: 1909-1920. - doi: 10.1111/j.1600-0706.2 011.19372.x

Martín-Benito D, Cherubini P, Del Río M, Cañellas I (2008). Growth response to climate and drought in Pinus nigra Arn. trees of different crown classes. Trees 22: 363-373. - doi: 10.1007/ s00468-007-0191-6

Orwig DA, Abrams MD (1997). Variation in radial growth responses to drought among species, site, and canopy strata. Trees 11: 474-484. - doi: 10.1007/s004680050110

Pretzsch H (2010). Forest dynamics, growth and yield. Springer, Berlin, Heidelberg, Germany, pp. 664. - doi: 10.1007/978-3-540-88307-4

Pretzsch H, Schütze G, Uhl E (2013). Resistance of European tree species to drought stress in mixed versus pure forests: evidence of stress release by inter-specific facilitation. Plant Biology 15: 483-495. - doi: 10.1111/j.1438-8677.2012. 00670.x

Rais A, Van Den Kuilen J-WG, Pretzsch H (2014). Growth reaction patterns of tree height, diameter, and volume of Douglas-fir (Pseudotsuga menziesii [Mirb. ] Franco) under acute drought stress in Southern Germany. European Journal of Forest Research 133: 1043-1056. - doi: 10.10 07/s10342-014-0821-7

Reyer C, Lasch-Born P, Suckow F, Gutsch M, Murawski A, Pilz T (2014). Projections of regional changes in forest net primary productivity for different tree species in Europe driven by climate change and carbon dioxide. Annals of Forest Science 71: 211-225. - doi: 10.1007/s13595013-0306-8

Salminen $H$, Jalkanen $R$, Lindholm $M$ (2009). Summer temperature affects the ratio of radial and height growth of Scots pine in northern Finland. Annals of Forest Science 66: 810. - doi: $10.1051 /$ forest $/ 2009074$

Schweingruber $\mathrm{FH}$ (1996). Tree rings and environment: dendroecology. Paul Haupt AG, Berne, Switzerland, pp. 609. [online] URL: http:// www.cabdirect.org/cabdirect/abstract/199806 02476

Schweingruber FH, Eckstein D, Serre-Bachet F, Bräker OU (1990). Identification, presentation and interpretation of event years and pointer years in dendrochronology. Dendrochronologia 8: 9-38. [online] URL: http://www.cabdirect.org /cabdirect/abstract/19930665561

Skovsgaard JP, Vanclay JK (2008). Forest site productivity: a review of the evolution of dendrometric concepts for even-aged stands. For estry 81: 13-31. - doi: 10.1093/forestry/cpmo41

Sohn JA, Kohler M, Gessler A, Bauhus J (2012). Interactions of thinning and stem height on the drought response of radial stem growth and isotopic composition of Norway spruce (Picea abies). Tree Physiology 32: 1199-1213. - doi: 10.10 93/treephys/tps077

Speer JH (2010). Fundamentals of tree-ring research. University of Arizona Press, Tucson, USA, pp. 333. [online] URL: http://books.goo gle.com/books?id=XtxEbbCzbKUUC

Sánchez-Salguero R, Camarero JJ, Dobbertin $M$, Fernández-Cancio A, Vilà-Cabrera A, Manzanedo RD, Zavala MA, Navarro-Cerrillo RM (2013). Contrasting vulnerability and resilience to drought-induced decline of densely planted $v$ s. natural rear-edge Pinus nigra forests. Forest Ecology and Management 310: 956-967. - doi: 10.1016/j.foreco.2013.09.050

Van Der Maaten-Theunissen M, Van Der Maaten $E$, Bouriaud O (2015). pointRes: an R package to analyze pointer years and components of resilience. Dendrochronologia 35: 34-38. - doi: 10.1016/j.dendro.2015.05.006

Vizcaíno-Palomar N, Ibáñez I, Benito-Garzón M, González-Martínez SC, Zavala MA, Alía R (2017). Climate and population origin shape pine tree height-diameter allometry. New Forests 48: 363-379. - doi: 10.1007/s11056-016-9562-4

\section{Supplementary Material}

Fig. S1 - Linear regressions that relate temperature and precipitation data from El Burgo de Osma and Bayubas de Abajo weather stations.

Link: Rubio-Cuadrado_2318@supplo01.pdf 